\title{
A buffered media system for yeast batch culture growth
}

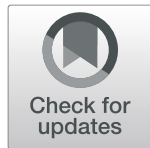

Rianne C. Prins and Sonja Billerbeck (1)

\begin{abstract}
Background: Fungi are premier hosts for the high-yield secretion of proteins for biomedical and industrial applications. The stability and activity of these secreted proteins is often dependent on the culture $\mathrm{pH}$. As yeast acidifies the commonly used synthetic complete drop-out (SD) media that contains ammonium sulfate, the pH of the media needs to be buffered in order to maintain a desired extracellular $\mathrm{pH}$ during biomass production. At the same time, many buffering agents affect growth at the concentrations needed to support a stable $\mathrm{pH}$. Although the standard for biotechnological research and development is shaken batch cultures or microtiter plate cultures that cannot be easily automatically $\mathrm{pH}$-adjusted during growth, there is no comparative study that evaluates the buffering capacity and growth effects of different media types across pH-values in order to develop a pH-stable batch culture system.

Results: We systematically test the buffering capacity and growth effects of a citrate-phosphate buffer (CPB) from acidic to neutral pH across different media types. These media types differ in their nitrogen source (ammonium sulfate, urea or both). We find that the widely used synthetic drop-out media that uses ammonium sulfate as nitrogen source can only be effectively buffered at buffer concentrations that also affect growth. At lower concentrations, yeast biomass production still acidifies the media. When replacing the ammonium sulfate with urea, the media alkalizes. We then develop a medium combining ammonium sulfate and urea which can be buffered at low CPB concentrations that do not affect growth. In addition, we show that a buffer based on $\mathrm{Tris} / \mathrm{HCl}$ is not effective in maintaining any of our media types at neutral $\mathrm{pH}$ even at relatively high concentrations.

Conclusion: Here we show that the buffering of yeast batch cultures is not straight-forward and addition of a buffering agent to set a desired starting $\mathrm{pH}$ does not guarantee $\mathrm{pH}$-maintenance during growth. In response, we present a buffered media system based on an ammonium sulfate/urea medium that enables relatively stable $\mathrm{pH}$ maintenance across a wide pH-range without affecting growth. This buffering system is useful for protein-secretionscreenings, antifungal activity assays, as well as for other $\mathrm{pH}$-dependent basic biology or biotechnology projects.
\end{abstract}

Keywords: Yeast, Growth medium, Buffer, pH, Secreted proteins

* Correspondence: s.k.billerbeck@rug.nl

Molecular Microbiology, Groningen Biomolecular Sciences and

Biotechnology Institute, University of Groningen, Groningen, The Netherlands

(c) The Author(s). 2021 Open Access This article is licensed under a Creative Commons Attribution 4.0 International License, which permits use, sharing, adaptation, distribution and reproduction in any medium or format, as long as you give appropriate credit to the original author(s) and the source, provide a link to the Creative Commons licence, and indicate if changes were made. The images or other third party material in this article are included in the article's Creative Commons licence, unless indicated otherwise in a credit line to the material. If material is not included in the article's Creative Commons licence and your intended use is not permitted by statutory regulation or exceeds the permitted use, you will need to obtain permission directly from the copyright holder. To view a copy of this licence, visit http://creativecommons.org/licenses/by/4.0/ The Creative Commons Public Domain Dedication waiver (http://creativecommons.org/publicdomain/zero/1.0/) applies to the data made available in this article, unless otherwise stated in a credit line to the data. 


\section{Background}

The extracellular $\mathrm{pH}$ is an important environmental factor, both for the functioning of fungi in their natural habitats as well as for engineered functionalities of fungi in the shake flask of a biotechnologist.

Unicellular fungi such as the yeasts Saccharomyces cerevisiae or Kluyveromyces lactis are widely used cell factories for the secretion of recombinant proteins $[1,2]$. Many secreted proteins require a specific culture $\mathrm{pH}$ to stay functional. For example, antifungal proteins (socalled yeast killer toxins) often require a low $\mathrm{pH}$ to be functional [3]. Other proteins, such as $\alpha$-galactosidase, have shown to require a neutral culture $\mathrm{pH}$ and lose activity in media that acidifies during biomass production [4]. Further, the stability and potency of many small molecule antifungals is $\mathrm{pH}$ dependent $[5,6]$.

As such, protein $\mathrm{pH}$ activity profiling, antifungal testing and determination of minimal inhibitory concentrations should ideally be performed at a defined $\mathrm{pH}$.

In a similar way, the action of yeast antibiotics that are commonly used for selection purposes in genetic engineering (e.g. G418 or Nourseothricin) are also dependent on a neutral culture $\mathrm{pH}$ for functionality [7].

$\mathrm{pH}$ is furthermore an important environmental trigger, influencing metabolism $[8,9]$, life-span [10], metabolite production performance [11], biofilm formation and virulence [12-15] of various biotechnologically or medically relevant yeast, and thus important when performing fundamental science experiments as well.

Growth in shaken batch cultures, microtiter plates or on solid agar plates are the leading experimental set-ups for basic fungal biology studies or biotechnological developments. These set-ups do not allow for automated $\mathrm{pH}$ maintenance and the media needs to be buffered to maintain a desired culture $\mathrm{pH}$ during biomass production. Using a reliable buffering system provided in sufficient concentration is important as biomass production leads to strong acidification of the most commonly used synthetic drop-out media that employs ammonium sulfate as nitrogen source [4]. At the same time we observed in our experiments that high concentrations of a buffering agent (e.g. Tris buffer, acetate buffer and citric acid) can affect growth in a $\mathrm{pH}$ dependent manner.

Especially, low $\mathrm{pH}$ buffering $(\mathrm{pH}<5)$ of yeast media is challenged by the fact that the only cheaply available buffering agents are weak organic acids like acetate or citric acid. Acetate is known to be toxic to cells at $\mathrm{pH}$ values below its dissociation constant $(\mathrm{p} K \mathrm{a}=4.76)$ [16, 17]. The then predominantly protonated form can enter cells via passive diffusion, leading to acidification of the cytosol and thus forcing the cell to invest energy (ATP) into maintaining a neutral cytosol [18]. Also citric acid is known to affect growth at high concentrations: with three carboxyl groups, citrate is a chelating compound and complexes several trace elements needed for growth [19]. Another buffering option is potassium hydrogen phthalate (KHP) but its high price makes it unsuitable for media development [19].

Most studies that require to work with a precisely adjusted low media $\mathrm{pH}$ use citric acid as part of the citrate phosphate buffer system (CPB) also known as McIlvaine buffer [20]. CPB is practical for media development for two reasons: first, the tri-protic nature of citric acid and disodium phosphate with three $\mathrm{pKa}$ values each, allows to buffer across a wide range of $\mathrm{pH}$ values $(\mathrm{pH} 2.2$ to $\mathrm{pH}$ 8.0). Second, CPB allows to set a desired $\mathrm{pH}$ using defined volumes of citric acid and $\mathrm{Na}_{2} \mathrm{HPO}_{4}$ stock solutions. This is practical as no $\mathrm{pH}$ adjustment after media mixing is necessary and various $\mathrm{pH}$ values can be rapidly mixed from the same stock solutions. Unfortunately, often no exact protocols for media preparation or data on $\mathrm{pH}$ stability and growth in different media types are provided [21-25].

Despite the importance of $\mathrm{pH}$ maintenance for the development of bioprocesses in shaken batch cultures or microtiter plates there are to our knowledge yet no systematic studies that compare or develop a buffered media system that uses necessary but sufficient concentrations of a buffer agent in order to reliably maintain a desired culture $\mathrm{pH}$ across a wide $\mathrm{pH}$ range without affecting growth. As such, the goal of our study was to develop such a buffered growth media for $S$. cerevisiae that is also applicable to other biotechnologically relevant yeast; herein tested for $K$. lactis. Because of the practicality of the CPB we decided to make that the basis of this buffered media system.

\section{Results}

The initial media $\mathrm{pH}$ and the $\mathrm{pH}$-change over biomass production in unbuffered SD media can be modulated with the nitrogen source

The widely used synthetic complete drop-out (SD) media that uses $2 \%$ glucose as carbon source and ammonium sulfate $\left(\mathrm{AS},\left(\mathrm{NH}_{4}\right)_{2} \mathrm{SO}_{4}\right)$ as sole nitrogen source acidifies during biomass production $[4,26,10]$. It was discussed that this acidification is due to the stoichiometric release of protons during the consumption of ammonium salts [4], others studies report the accumulation of organic acids in the culture medium [10]. It has also been shown that acidification can be circumvented by replacing ammonium sulfate with urea as nitrogen source, or by decreasing the glucose concentration [4, 26]. As decreasing the glucose concentrations changes biomass yield - an important factor for biotechnological processes - we decided to not vary the carbon source but rather use the nitrogen source for $\mathrm{pH}$ modulation. We first re-tested the change in $\mathrm{pH}$ over biomass production in normal SD media with ammonium sulfate 

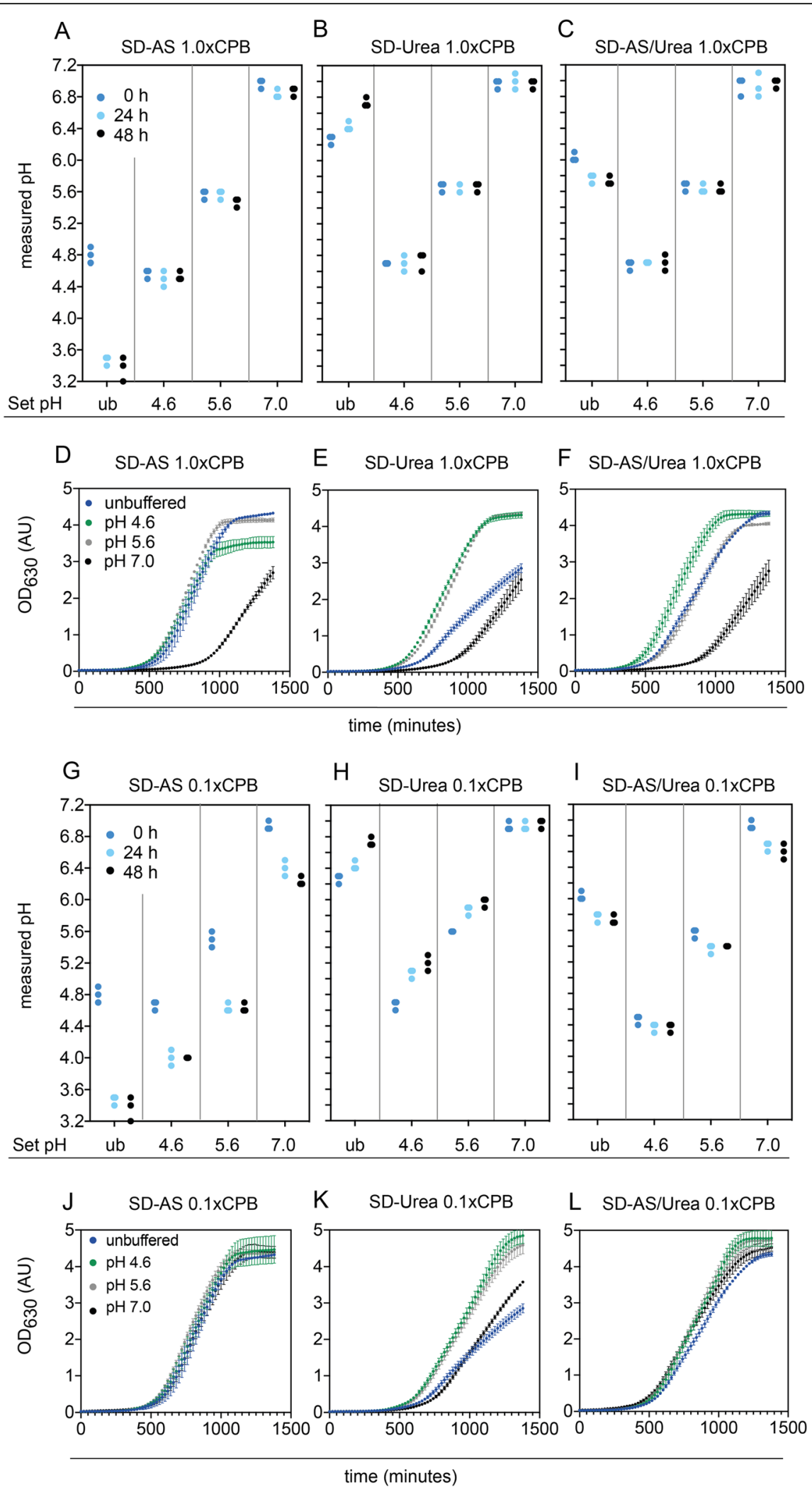

Fig. 1 (See legend on next page.) 


\section{(See figure on previous page.)}

Fig. $1 \mathrm{pH}$ stability and growth under unbuffered conditions or when using 1.0x and $0.1 \times \mathrm{CPB}$ across different media types and $\mathrm{pH}$ values. a-c: $\mathrm{pH}$ stability over $48 \mathrm{~h}$ in unbuffered (ub) media and across three $\mathrm{pH}$ values when using 1.0x CPB in SD-AS media $\mathbf{a}$, SD-Urea media $\mathbf{b}$ and SD-AS/ Urea media c. Individual values of triplicates are plotted. d-f: Growth across unbuffered (ub) media and when using 1.0x CPB in SD-AS media d, SD-Urea media e and SD-AS/Urea media $\mathbf{f}$. Error bars represent the standard deviation of triplicates. $\mathbf{g}$-i: $\mathbf{p H}$ stability in unbuffered (ub) media and across three $\mathrm{pH}$ values when using $0.1 \times$ CPB in SD-AS media $\mathbf{g}$, SD-Urea media $\mathbf{h}$ and SD-AS/Urea media $\mathbf{i}$. Individual values of triplicates are plotted. $\mathbf{j}-\mathbf{l}$ : Growth across unbuffered media and when using 1.0x CPB in SD-AS media $\mathbf{j}$, SD-Urea media $\mathbf{h}$ and SD-AS/Urea media I. Error bars represent the standard deviation of triplicates

(herein called SD-AS media, $5 \mathrm{~g} / \mathrm{L} \mathrm{AS}$ ), and in SD media with the ammonium sulfate replaced by urea (SD-Urea media, $5 \mathrm{~g} / \mathrm{L}$ urea). Throughout the study we used the $S$. cerevisiae strain BY4741 as test case. As expected, the normal SD-AS media showed an average starting $\mathrm{pH}$ of 4.8 and was acidified during biomass production over $48 \mathrm{~h}$ to an average $\mathrm{pH}$ of 3.4 (Fig. $1 \mathrm{~A}$, left panel). SDUrea media showed a starting $\mathrm{pH}$ of 6.3 and slightly alkalized during biomass production to a $\mathrm{pH}$ of 6.7 (Fig. 1 B, left panel). Alkalization of urea media was also observed in a previous study with $K$. lactis [4]. As the use of ammonium sulfate leads to acidification of the media and the use of urea to alkalization, we were interested if a mixture of both nitrogen sources could modulate the $\mathrm{pH}$ change during biomass production in unbuffered media. We herein tested a 1:1 ratio $(\mathrm{w} / \mathrm{w})$ and the corresponding media will be referred to as SDAS/Urea media ( $2.5 \mathrm{~g} / \mathrm{L}$ AS and $2.5 \mathrm{~g} / \mathrm{L}$ urea). Indeed, biomass production only slightly acidified this media, with its $\mathrm{pH}$ dropping from 6.1 to 5.7 over the course of $48 \mathrm{~h}$ (Fig. $1 \mathrm{C}$, left panel).

\section{The $\mathrm{pH}$ stability of CP-buffered media is enhanced when using a mixture of ammonium sulfate and urea as nitrogen source}

Next, we tested if the $\mathrm{pH}$ of each media type could be effectively buffered with $\mathrm{CPB}$ and we chose $\mathrm{pH} 4.6, \mathrm{pH} 5.6$ and $\mathrm{pH} 7.0$ as our test values. This $\mathrm{pH}$ range is most important for our work with small molecule antifungals and proteinaceous killer toxins which all show $\mathrm{pH}$ dependent functionalities. Further, media buffered at $\mathrm{pH} 7.0$ is relevant for growth selections with commonly used antibiotic markers [7]. The herein used 1.0x CPB recipe adjusts the media $\mathrm{pH}$ with defined volumes of sterile stock solutions of $1 \mathrm{M}$ citric acid and $1 \mathrm{M} \mathrm{Na} \mathrm{NPO}_{4}$ (Supplementary Table S1). In order to allow for simple media preparation from sufficiently concentrated stock solutions, we adjusted the stock concentrations and the required volumes from the original buffer table that uses $0.2 \mathrm{M} \mathrm{Na}_{2} \mathrm{HPO}_{4}$ and 0.1 $M$ citric acid [20].

The final concentration of citric acid and $\mathrm{Na}_{2} \mathrm{HPO}_{4}$ in the media depends on the desired $\mathrm{pH}$. For the tested $\mathrm{pH}$ values, they ranged between $17.6 \mathrm{mM}$ and $53.2 \mathrm{mM}$ citric acid and $93.5 \mathrm{mM}$ and $164.7 \mathrm{mM} \mathrm{Na} \mathrm{HPO}_{4}$. In order to determine differences in the buffering capacity as well as to determine the minimal $\mathrm{CPB}$ concentration required to achieve $\mathrm{pH}$ stability, we tested $\mathrm{pH}$ stability in media buffered with 0.1x CPB (10 times less of the above indicated concentrations). Experiments were performed in $50 \mathrm{ml}$ liquid culture in $125 \mathrm{ml}$ shake flasks. The $\mathrm{pH}$ was measured by taking $7 \mathrm{ml}$ samples before inoculation $(0$ h) and after $24 \mathrm{~h}$ and $48 \mathrm{~h}$ of growth. Fig. $1 \mathrm{~A}-\mathrm{C}$ shows that 1.0x CPB allowed to adjust and maintain the media $\mathrm{pH}$ at its intended value for all media types. In contrast to $1.0 \mathrm{x} \mathrm{CPB}, 0.1 \mathrm{x} \mathrm{CPB}$ was not sufficient to maintain the $\mathrm{pH}$ of SD-AS media and SD-Urea media. The media either acidified or alkalized (Fig. $1 \mathrm{G}$ and $\mathrm{H}$ ). Only in the case of SD-AS/Urea media the $\mathrm{pH}$ stayed relatively stable ( $\mathrm{pH}$ changes: from average $\mathrm{pH} 4.5$ to 4.4, from pH 5.6 to 5.4, from pH 6.9 to 6.6) (Fig. 1 I).

\section{CPB affects growth in a concentration dependent manner}

Besides $\mathrm{pH}$ stability we were also interested in potential growth defects caused by the buffering agents or the $\mathrm{pH}$. Therefore, we measured full growth curves for each media type and each $\mathrm{pH}$ compared to unbuffered media. Fig. $1 \mathrm{D}$-F shows that 1.0x CPB caused $\mathrm{pH}$-dependent growth effects across all media types when compared to the unbuffered media control. For example, across all media types, buffering to $\mathrm{pH} 7.0$ showed long lag phases and decreased growth rates (Supplementary Fig. S1). On the contrary, buffering to $\mathrm{pH} 4.6$ and 5.6 showed enhanced growth rates in SD-Urea media, and buffering to $\mathrm{pH} 4.6$ showed higher growth rates in SD-AS/Urea media (Supplementary Fig. S1). Buffering with 0.1x CPB allowed for normal growth in SD-AS and SD-AS/Urea media across all $\mathrm{pH}$ values. Noteworthy, while growth rates in unbuffered SD-AS and SD-AS/Urea were comparable, growth in SD-Urea media showed a much longer lag phase and slower growth rate (Supplementary Fig. S1B). As the SD-AS/Urea showed better pH performance we were - for the purpose of this study - not further interested in optimizing growth performance in SD-Urea media; thus, we excluded the SD-Urea media from further experiments.

In summary, at this point, $0.1 \mathrm{x}$ CP-buffered SD-AS/ Urea media performed the best for our purpose. This media type allowed for normal growth across all tested $\mathrm{pH}$ values as well as it maintained all $\mathrm{pH}$ levels reasonably stable across biomass production (average $\mathrm{pH}$ 
changes: from $\mathrm{pH} 4.5$ to 4.4 , from $\mathrm{pH} 5.5$ to 5.4 and from $\mathrm{pH} 6.9$ to 6.4).

Still, as the $\mathrm{pH}$ maintenance at $0.1 \mathrm{x} \mathrm{CPB}$ was not perfect we further tested if $\mathrm{pH}$ stability could be enhanced in $0.2 \mathrm{x}$ and $0.5 \mathrm{x} \mathrm{CPB}$, while maintaining stable growth. In terms of growth, both concentrations caused the same long lag phase for $\mathrm{pH} 7.0$, but the growth phenotypes at $\mathrm{pH} 4.6$ and 5.6 were not altered for both media types (Fig. $2 \mathrm{E}-\mathrm{H}$ and Supplementary Fig. S2). In terms of $\mathrm{pH}$ change, the $\mathrm{pH}$ only changed slightly when SD-AS media was buffered with $0.5 \mathrm{x} C P B$, but significantly in the $0.2 \mathrm{x} \mathrm{CPB}$ case (Fig. $2 \mathrm{~A}$ and $\mathrm{C}$ ). In SD-AS/Urea media the $\mathrm{pH}$ remained stable for $0.5 \mathrm{x} \mathrm{CPB}$ and showed slight changes when buffered with $0.2 \mathrm{x}$ CPB (Fig. $2 \mathrm{~B}$ and $\mathrm{D})$. Those changes were comparable to the $0.1 \mathrm{x}$ CPB case (Fig. 1 I).

In summary, buffering with $0.5 \mathrm{x} \mathrm{CPB}$ appeared to be a suitable option for low $\mathrm{pH}$ buffering in either SD-AS media and SD-AS/Urea media (as tested for $\mathrm{pH} 4.6$ and pH 5.6).

\section{Tris/HCl does not effectively buffer the tested media} types at neutral $\mathrm{pH}$

So far, our results have shown that buffering at neutral $\mathrm{pH}$ is the most challenging. CPB concentrations above $0.1 \mathrm{x}$ caused strong growth effects at $\mathrm{pH} 7.0$ and were not enough to fully stabilize a neutral $\mathrm{pH}$ over biomass production. Several buffer agents with buffering capacities around neutral $\mathrm{pH}$ are available and widely used in biochemistry, molecular biology and microbiology. For example, Tris buffer has been used before to buffer yeast media a pH 7.0 [27]. Therefore, we tested if $10 \mathrm{mM}$ or $100 \mathrm{mM}$ Tris/ $\mathrm{HCl}$ adjusted to $\mathrm{pH} 7.0$ would be better suited for buffering at $\mathrm{pH}$ 7.0. We prepared media by supplementing SD-AS and SD-AS/Urea with appropriate amounts of a $500 \mathrm{mM}$ stock solution. First, we noticed that simply adding Tris buffer did not suffice to adjust the media $\mathrm{pH}$ to 7.0. It rather yielded a starting $\mathrm{pH}$ of 6.3 and 6.7 for SD-AS and SD-AS/Urea media respectively buffered with $100 \mathrm{mM}$ Tris/ $\mathrm{HCl} \mathrm{pH} 7.0$, and 6.1 and 6.3 for $10 \mathrm{mM}$ Tris/HCl pH 7.0. We then adjusted

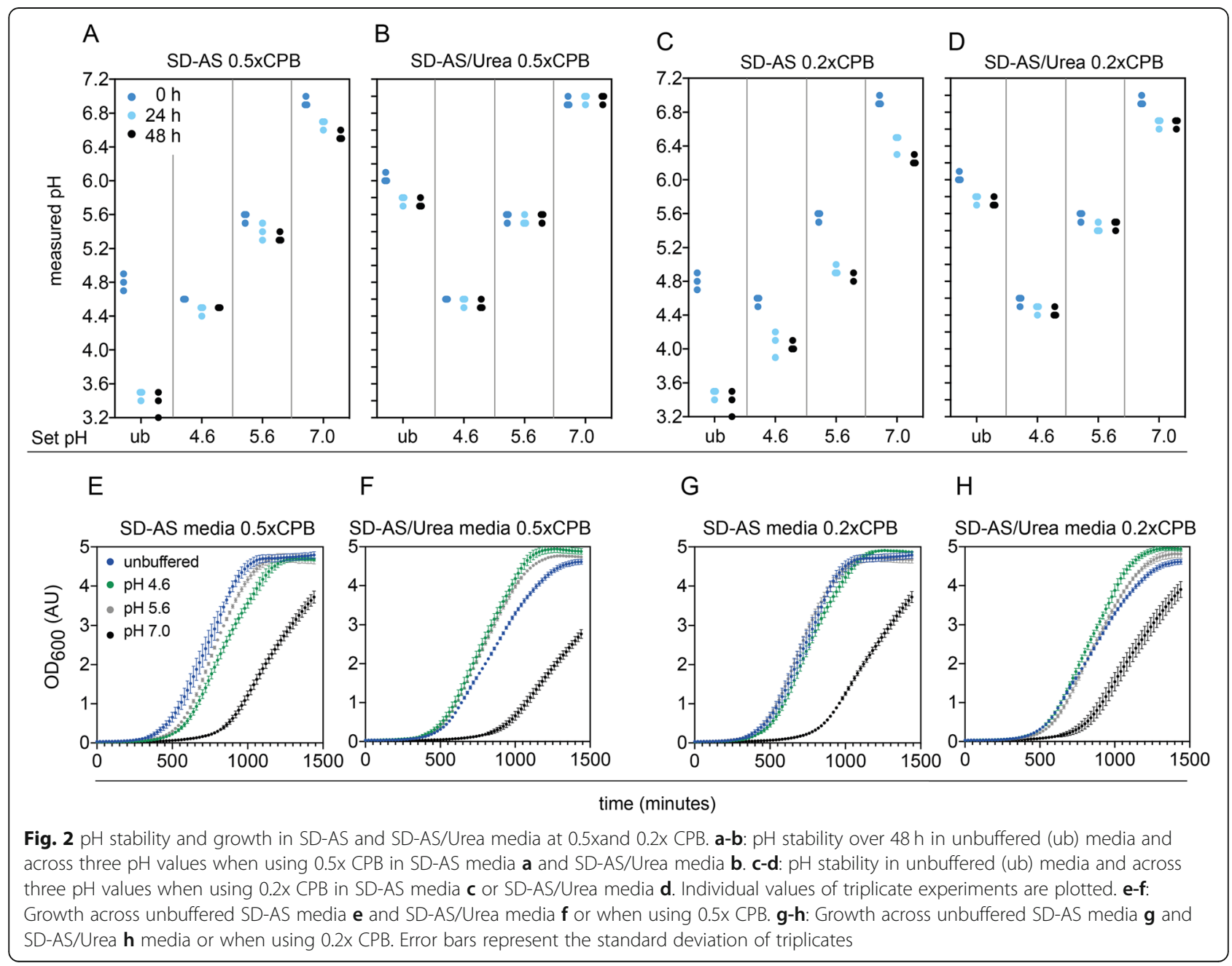


the media to $\mathrm{pH} 7.0$ with $5 \mathrm{M} \mathrm{NaOH}$ and followed the $\mathrm{pH}$ changes over $48 \mathrm{~h}$ biomass production. We observed that even $100 \mathrm{mM}$ Tris buffer was not sufficient to maintain the $\mathrm{pH}$ of either media. The $\mathrm{pH}$ dropped from $\mathrm{pH}$ 7.0 to 3.9 over $48 \mathrm{~h}$ of biomass production in SD-AS media (Fig. $3 \mathrm{~A}$ ) and from $\mathrm{pH} 7.0$ to 5.3 for SD-AS/Urea media (Fig. 3 B). Full growth curves demonstrate that $100 \mathrm{mM}$ Tris buffer slowed growth, whereas $10 \mathrm{mM}$ did not affect growth (Fig. $3 \mathrm{C}$ and D).
The best performing buffered media system is also suitable for other yeasts

Finally, we tested if our best performing buffered media system (SD-AS/Urea, $0.1 \mathrm{x}$ CPB) could also be used for buffering shake flask experiments of other biotechnologically relevant yeasts - such as K. lactis - across a wide $\mathrm{pH}$ range. We first verified that $K$. lactis shows no changed growth phenotype in media with part of the ammonium sulfate replaced by urea (Fig. 4 A). We further did
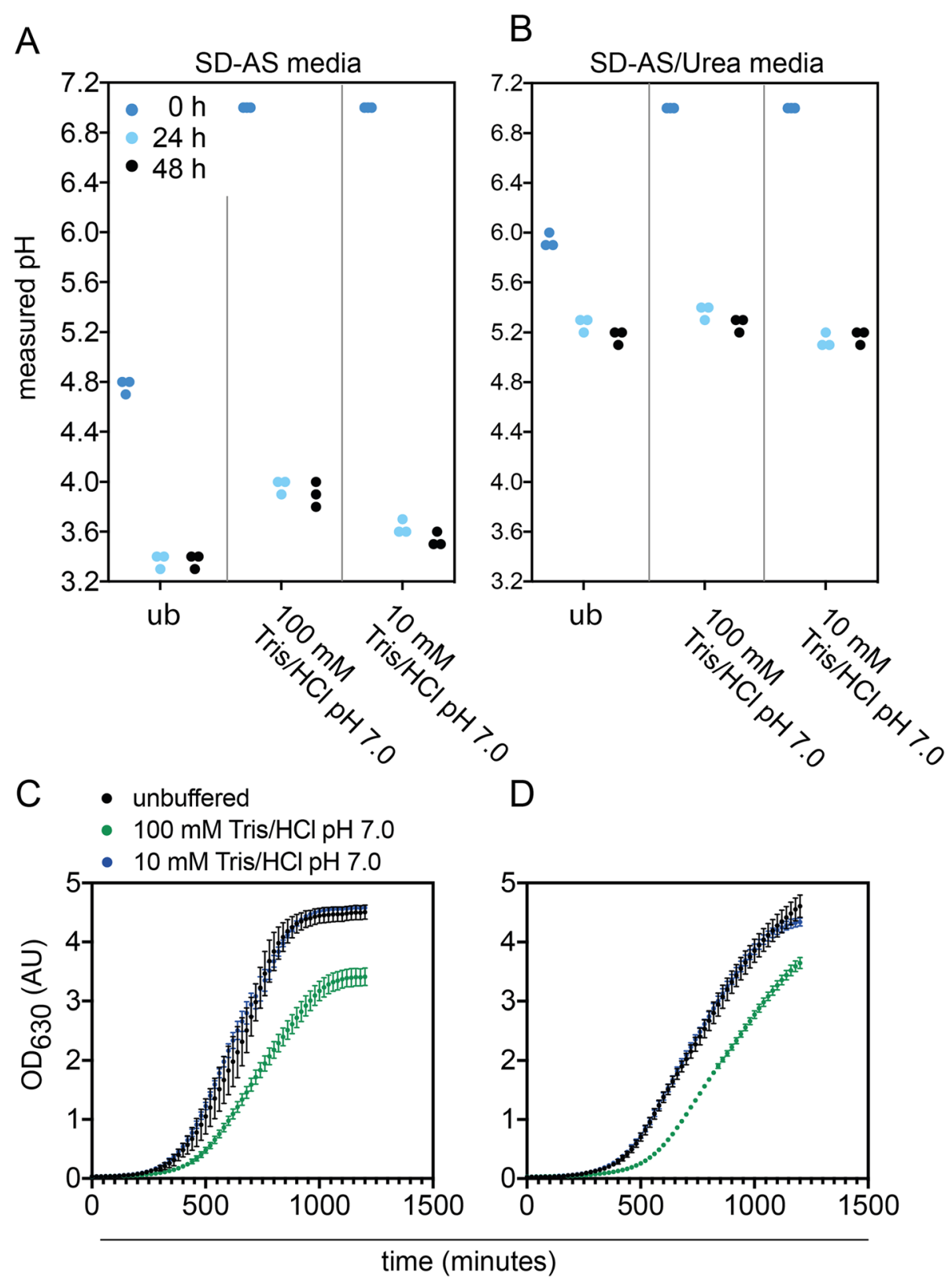

Fig. 3 pH stability and growth in Tris-buffered SD-AS and SD-AS/Urea media. a-b: pH stability over $48 \mathrm{~h}$ in unbuffered (ub) SD-AS a and SD-AS/ Urea media $\mathbf{b}$ and when buffered with $100 \mathrm{mM}$ or $10 \mathrm{mM}$ Tris/HCl pH 7.0. Individual values of triplicate experiments are plotted. c-d: Growth across unbuffered SD-AS media $\mathbf{c}$ and SD-AS/Urea media $\mathbf{b}$ or when buffered with $100 \mathrm{mM}$ or $10 \mathrm{mM}$ Tris/HCl pH 7.0. Error bars represent the standard deviation of triplicates 

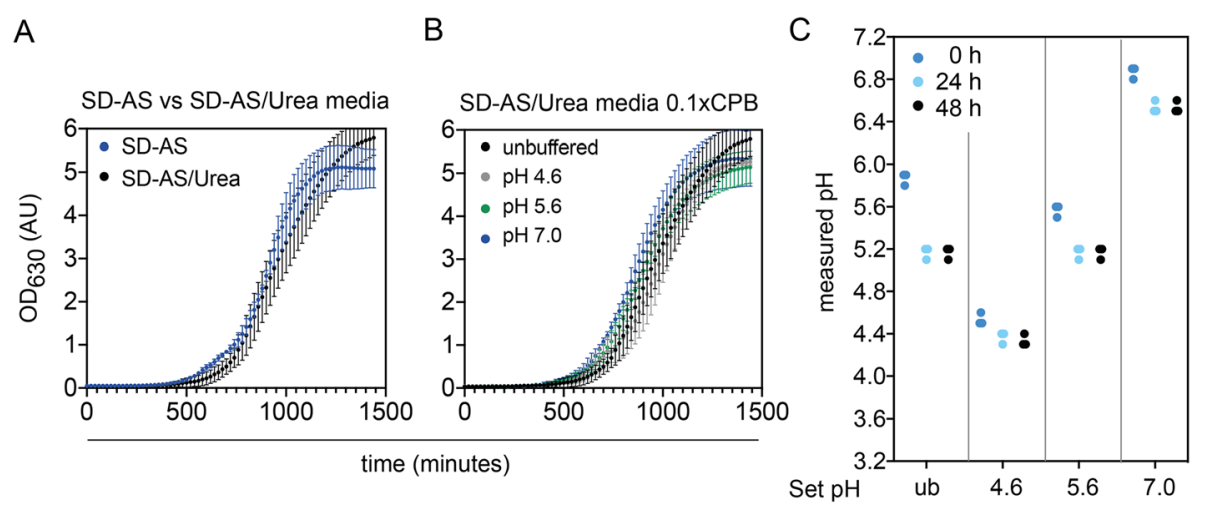

Fig. 4 pH stability and growth in 0.1x CPB SD-AS/Urea media for K. lactis. a: Overlay of growth curves of K. lactis in unbuffered SD-AS and SD-AS/ Urea media. b: Growth of K. lactis in unbuffered SD-AS/Urea media and when 0.1x CP-buffered at the indicated pH values. c: pH stability over 48 $\mathrm{h}$ in unbuffered (ub) SD-AS/Urea media and when buffered with $0.1 \times C P B$. Individual values of triplicate experiments are plotted

not observe any altered growth phenotypes in $K$. lactis in either medium across all $\mathrm{pH}$ values (Fig. 4 B). Similar as for $S$. cerevisiae, the $\mathrm{pH}$ was reasonably stable over biomass production (average $\mathrm{pH}$ changes: from $\mathrm{pH} 4.5$ to 4.3 , from $\mathrm{pH} 5.6$ to 5.2 and from $\mathrm{pH} 6.9$ to 6.5 ).

\section{Discussion}

Here we show that the effective buffering of yeast batch culture media is not straight-forward and requires some considerations in order to maintain a set $\mathrm{pH}$ and robust growth during biomass production. Media acidification by yeast has been observed before [4] as well as in this study. An important implication of this media acidification for existing and ongoing research is that a set culture $\mathrm{pH}$ (even when buffered) may change over biomass production, and that these $\mathrm{pH}$ changes may compromise interpretations of results in case the culture $\mathrm{pH}$ is an important experimental parameter. As such we recommend measuring the culture $\mathrm{pH}$ during or after growth in case of such $\mathrm{pH}$-sensitive experiments.

We demonstrate that the media type with both urea and ammonium sulfate as nitrogen sources, buffered with a citrate-phosphate buffer (SD-AS/Urea), has the best buffering capacity without affecting growth. This buffering system allows for accurate and stable $\mathrm{pH}$ maintenance over biomass production.

Concerning $\mathrm{pH}$ accuracy, we observed some technical details of importance when preparing the SD-AS/Urea media: First, when using newly prepared media stock solutions there can be a batch to batch variability in initial and final $\mathrm{pH}$. For example, our first batch of unbuffered SD-AS/Urea media showed a starting $\mathrm{pH}$ of 6.1 and dropped to $\mathrm{pH} 5.7$ over biomass production, while our second batch showed a starting $\mathrm{pH}$ of 6.0 and dropped to pH 5.2 (Fig. $1 \mathrm{C}$, left panel and Fig. $4 \mathrm{C}$, left panel). This might be due to slight variations in the ammonium sulfate and urea concentrations in the media. The buffering capacity in the presence of $0.1 \mathrm{x} C \mathrm{~PB}$ was not affected (Fig. 4 C). Second, slight differences can also arise when independently setting media $\mathrm{pH}$ for different solutions. In our study this can be observed in the starting $\mathrm{pH}$ of the triplicate 1.0x $\mathrm{CPB}$ experiments (Fig. $1 \mathrm{a}-$ c). In our experience, accurately pipetting the CPB solutions allows to adjust the media $\mathrm{pH}$ to an accuracy of plus minus $0.1 \mathrm{pH}$ values (in rare cases $0.2 \mathrm{pH}$ values). For simplicity, we did not further adjust the $\mathrm{pH}$ to the intended $\mathrm{pH}$ in those cases, but this is easily done by titrating in small amounts of one of the sterile stock solutions.

Buffering at $\mathrm{pH} 7.0$ proved to be the most challenging, as $\mathrm{CPB}$ concentrations required for $\mathrm{pH}$ maintenance caused a long lag phase and a lower final $\mathrm{OD}_{630}$ during growth. Tris buffer has been used before to buffer yeast media at $\mathrm{pH} 7.0$ [27], but $100 \mathrm{mM}$ Tris buffer ( $\mathrm{pH} 7.0)$ was not effective in our study to maintain neutral media $\mathrm{pH}$ in either tested medium. pH 7.0 falls at the lower end of the buffering capacity of the Tris buffer (range $\mathrm{pH}$ 7.0-9.0), and the decrease in $\mathrm{pH}$ was substantial. The observation that usual concentrations of buffers are not effective in buffering yeast media was made before: [8] For example, 10 to $30 \mathrm{mM}$ bicine(N,N-Bis (2-hydroxyethylglycine))-TEA (triethanolamine) was not enough to buffer complex yeast media (YPD) at $\mathrm{pH} 8.0$ or the same amounts of morpholino ethane sulfonic acid (MES)-TEA were not enough to buffer yeast media at pH 6.0.

Here, we did not test buffering systems with broader buffer capacity around pH 7.0, such as Bis-Tris (5.8-7.2). Bis-Tris has been used in mammalian cell cultures [28], but has not - to the best of our knowledge - been reported for use in yeast cultures. We did not test further buffers, as we found that $0.1 \mathrm{x}$ CPB in our SD-AS/Urea media worked reasonably well at maintaining $\mathrm{pH}$ 7.0. Still, it can be worthwhile testing other buffer systems if 
highly accurate $\mathrm{pH}$ maintenance around $\mathrm{pH} 7.0$ is required.

\section{Conclusion}

Using the herein presented cross-comparison we extract the following recommendations for buffering batch culture media for yeast:

1. Buffering at low $\mathrm{pH}<5$ (herein tested for $\mathrm{pH} 4.6$ ): For studies that require a fixed low $\mathrm{pH}$ and seek to maintain the use of the common synthetic drop-out media (SD media) with ammonium sulfate, reasonable buffering with no changes in growth can be achieved by using SD-AS 0.5x CPB media (average $\mathrm{pH}$ change from 4.6 to 4.4 over $48 \mathrm{~h}$ ). For studies that are flexible about the nitrogen source, we recommend to use SD-AS/Urea 0.5x CPB, as the buffering capacity is higher (no change in $\mathrm{pH}$ ). We recommend to re-test exact media conditions for $\mathrm{pH}$ values other than 4.6 (e.g. using the presented work flow).

2. Buffering at $\mathrm{pH} 5$ to 6 (herein tested for $\mathrm{pH}$ 5.6): We recommend the same as for point 1.

3. Buffering at neutral $\mathrm{pH}$ (herein tested for $\mathrm{pH}$ 7.0): We recommend to use SD-AS/Urea 0.1x CPB which did not cause growth defects and kept the $\mathrm{pH}$ reasonably stable.

4. Comparison across pH: For studies that seek to compare a specific trait across a wide range of $\mathrm{pH}$ values we recommend to use SD-AS/Urea $0.1 \mathrm{x}$ CPB.

\section{Methods}

\section{Materials}

Media and buffer components were obtained from $\mathrm{BD}$ Bioscience (Franklin Lakes, NJ, USA) and Sigma Aldrich (Darmstadt, Germany). Specifically yeast nitrogen base without amino acids and ammonium sulfate was obtained from Sigma and yeast nitrogen base without amino acids but with ammonium sulfate was obtained from BD Bioscience.

Sterile, transparent round-bottom microtiter plates were obtained from Corning (Corning Inc.).

\section{Strains}

Saccharomyces cerevisiae BY4741 [29] and Kluyveromyces lactis NRRL-Y-1140 (derived from ATCC) were used for $\mathrm{pH}$ measurements and growth experiments.

\section{Media preparation}

All media recipes are provided in Supplementary Tables S2, S3, S4, S5.
$\mathrm{pH}$ measurements

Cells were grown overnight in $8 \mathrm{ml}$ unbuffered SD-AS, SD-Urea or SD-AS/Urea medium. Triplicate shake flasks with $50 \mathrm{ml}$ of each buffered media type were prepared and the initial $\mathrm{pH}$ (zero-hour time point) of a $7 \mathrm{ml} \mathrm{sam-}$ ple was measured using a $\mathrm{pH}$ meter from Hanna Instruments 8520 (Nieuwegein, Netherlands). Each flask was then inoculated from the appropriate overnight culture (e.g. all buffered SD-AS media were inoculated from the unbuffered SD-AS medium culture) with a starting $\mathrm{OD}_{630}$ of 0.1 . After $24 \mathrm{~h}$ and $48 \mathrm{~h} \mathrm{a} 7 \mathrm{ml}$ sample was taken, cells were separated by centrifugation for $30 \mathrm{~min}$ at $4000 \mathrm{rpm}$ in a Beckman Coulter Allegra X-15R centrifuge, and $\mathrm{pH}$ of the supernatant was measured after transfer into a fresh tube.

\section{Growth measurements}

Growth curves across media types were recorded in sterile, transparent round-bottom 96-well plates using $200 \mu \mathrm{l}$ total culture volume, cultured at $30^{\circ} \mathrm{C}$ in a SynergyMx plate reader (high orbital shaking). Cells were seeded at an $\mathrm{OD}_{630}$ of approximately 0.03 and culture turbidity $\left(\mathrm{OD}_{630}\right)$ was recorded every $20 \mathrm{~min}$ for 20 to $24 \mathrm{~h}$. Since the later optical density values were outside the linear range of the photodetector, all optical density values were first corrected using the following formula to calculate true optical density values:

$$
O D_{\text {true }}=\frac{k \cdot O D_{\text {meas }}}{O D_{\text {sat }}-O D_{\text {meas }}}
$$

where $O D_{\text {meas }}$ is the measured optical density, $O D_{\text {sat }}$ is the saturation value of the photodetector ( 2.568 for our instrument, as experimentally determined) and $k$ is the true optical density at which the detector reaches half saturation of the measured optical density ( 2.075 for our instrument, as experimentally determined). Specific growth rates were determined by linear regression of the manually determined linear range of the $\log 2\left(\mathrm{OD}_{630}\right)$ versus time plots of each growth curve.

\section{Supplementary Information}

The online version contains supplementary material available at https://doi. org/10.1186/s12866-021-02191-5.

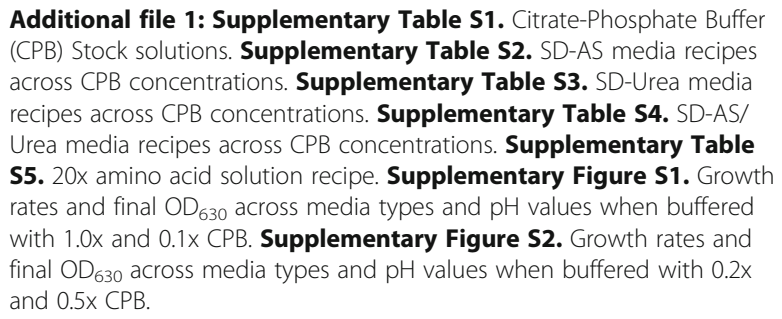

Additional file 1: Supplementary Table S1. Citrate-Phosphate Buffer (CPB) Stock solutions. Supplementary Table S2. SD-AS media recipes across CPB concentrations. Supplementary Table S3. SD-Urea media recipes across CPB concentrations. Supplementary Table S4. SD-AS/ Urea media recipes across CPB concentrations. Supplementary Table S5. 20x amino acid solution recipe. Supplementary Figure S1. Growth rates and final $\mathrm{OD}_{630}$ across media types and $\mathrm{pH}$ values when buffered with 1.0x and 0.1x CPB. Supplementary Figure S2. Growth rates and final $\mathrm{OD}_{630}$ across media types and $\mathrm{pH}$ values when buffered with $0.2 \mathrm{x}$ and $0.5 \times \mathrm{CPB}$.

Acknowledgements Not applicable. 


\section{Authors' contributions}

R.C.P and S.B. designed and performed the experiments. SB wrote the manuscript. All authors read and approved the final manuscript.

\section{Funding}

The study was partly funded by NWO XS award OCENW.XS3.069 (SB). The funding body had no role in the design of the study and collection, analysis, and interpretation of data and in writing the manuscript.

\section{Availability of data and materials}

The datasets used and/or analysed during the current study are available from the corresponding author on reasonable request.

\section{Declarations}

\section{Ethics approval and consent to participate}

Not applicable.

\section{Consent for publication}

Not applicable.

\section{Competing interests}

The authors declare that they have no competing interests.

Received: 24 January 2021 Accepted: 11 April 2021

Published online: 23 April 2021

\section{References}

1. Love KR, Dalvie NC, Love JC. The yeast stands alone: the future of protein biologic production. Curr Opin Biotechnol. 2018;53:50-8.

2. Roohvand F, Shokri M, Abdollahpour-Alitappeh M, Ehsani P. Biomedical applications of yeast- a patent view, part one: yeasts as workhorses for the production of therapeutics and vaccines. Exp Opin Ther Patents. 2017;27: 929-51

3. Mannazzu I, et al. Yeast killer toxins: from ecological significance to application. Crit Rev Biotechnol. 2019:39:603-17.

4. Hensing MCM, et al. Effects of cultivation conditions on the production of heterologous a-galactosidase by Kluyveromyces lactis. Appl Microbiol Biotechnol. 1995;43:58-64.

5. Te Dorsthorst DTA, et al. Effect of $\mathrm{pH}$ on the in vitro activities of amphotericin B, itraconazole, and flucytosine against Aspergillus isolates. Antimicrob Agents Chemother. 2004;48:3147-50

6. Liu W, Zhang X, Liu Z, Luo X. Impact of pH on the antifungal susceptibility of vaginal Candida albicans. Int J Gynecol Obstet. 2011;114:278-80.

7. Vickers CE, Bydder SF, Zhou Y, Nielsen LK. Dual gene expression cassette vectors with antibiotic selection markers for engineering in Saccharomyces cerevisiae. Microb Cell Fact. 2013:12:96.

8. Peña A, Sánchez NS, Álvarez H, Calahorra M, Ramírez J. Effects of high medium pH on growth, metabolism and transport in Saccharomyces cerevisiae. FEMS Yeast Res. 2015;15:5.

9. Nielsen MK, Arneborg N. The effect of citric acid and $\mathrm{pH}$ on growth and metabolism of anaerobic Saccharomyces cerevisiae and Zygosaccharomyces bailii cultures. Food Microbiol. 2007;24:101-5

10. Burtner CR, Murakami CJ, Kennedy BK, Kaeberlein M. A molecular mechanism of chronological aging in yeast. Cell Cycle. 2009;8:1256-70.

11. Buzás Z, Dallmann K, Szajáni B. Influenc of pH on the growth and ethanol production of free and immobilized Saccharomyces cerevisiae cells. Biotechnol Bioeng. 1989:34:882-4.

12. de Vasconcellos AA, Gonçalves LM, Del Bel Cury AA, Da Silva WJ. Environmental $\mathrm{pH}$ influences Candida albicans biofilms regarding its structure, virulence and susceptibility to fluconazole. Microb Pathog. 2014; 69-70:39-44.

13. Ferreira $\mathrm{C}$, et al. Candida tropicalis biofilm and human epithelium invasion is highly influenced by environmental pH. Pathog Dis. 2016;74:ftw101.

14. Sherrington $\mathrm{SL}$, et al. Adaptation of Candida albicans to environmental $\mathrm{pH}$ induces cell wall remodelling and enhances innate immune recognition. PLOS Pathog. 2017;13:e1006403.

15. Lohse MB, Gulati M, Johnson AD, Nobile CJ. Development and regulation of single-and multi-species Candida albicans biofilms. Nat Rev Microbiol. 2018; 16:19-31.
16. Narendranath NV, Thomas KC, Ingledew WM. Effects of acetic acid and lactic acid on the growth of Saccharomyces cerevisiae in a minimal medium. J Ind Microbiol Biotechnol. 2001;26:171-7.

17. Graves T, Narendranath NV, Dawson K, Power R. Effect of pH and lactic or acetic acid on ethanol productivity by Saccharomyces cerevisiae in corn mash. J Ind Microbiol Biotechnol. 2006;33:469-74.

18. Pampulha ME, Loureiro-Dias MC. Energetics of the effect of acetic acid on growth of Saccharomyces cerevisiae. FEMS Microbiol Lett. 2000;184:69-72.

19. Hahn-Hägerdal $B$, et al. Role of cultivation media in the development of yeast strains for large scale industrial use. Microbial Cell Factor. 2005;4:31.

20. Mcllvaine TC. A buffer solution for colorimetric comparison. J Biol Chem. 1921:49:183-6

21. Soares GAM, Sato HH. Characterization of the Saccharomyces cerevisiae Y500-4 L killer toxin. Braz J Microbiol. 2000;31:291-7.

22. Wang $X$, et al. A marine killer yeast against the pathogenic yeast strain in crab (Portunus trituberculatus) and an optimization of the toxin production. Microbiol. Res. 2007;162:77-85.

23. Flegelova H, Novotna D, Vojta-Akova K, Janderova B. Isolation and characterization of Saccharomyces cerevisiae mutants with a different degree of resistance to killer toxins K1 and K2. FEMS Yeast Res. 2002:2:73-9.

24. Gier S, et al. Transcriptome kinetics of Saccharomyces cerevisiae in response to Viral killer toxin K1. Front Microbiol. 2019:10:1102.

25. Villalba ML, Mazzucco MB, Lopes CA, Ganga MA, Sangorrín MP. Purification and characterization of Saccharomyces eubayanus killer toxin: Biocontrol effectiveness against wine spoilage yeasts. Int J Food Microbiol. 2020;331: 108714.

26. González-Ramos D, et al. A new laboratory evolution approach to select for constitutive acetic acid tolerance in Saccharomyces cerevisiae and identification of causal mutations. Biotechnol Biofuels. 2016;9:173.

27. Kaeberlein, $\mathrm{M}$. et al. Buffering the $\mathrm{pH}$ of the culture medium does not extend yeast replicative lifespan. F1000Research 2, (2013).

28. Eagle H. Buffer combinations for mammalian cell culture. Science. 1971;174: 500-3.

29. Baker Brachmann C, et al. Designer deletion strains derived from Saccharomyces cerevisiae S288C: A useful set of strains and plasmids for PCRmediated gene disruption and other applications. Yeast. 1998;14:115-32

\section{Publisher's Note}

Springer Nature remains neutral with regard to jurisdictional claims in published maps and institutional affiliations.

Ready to submit your research? Choose BMC and benefit from:

- fast, convenient online submission

- thorough peer review by experienced researchers in your field

- rapid publication on acceptance

- support for research data, including large and complex data types

- gold Open Access which fosters wider collaboration and increased citations

- maximum visibility for your research: over $100 \mathrm{M}$ website views per year

At BMC, research is always in progress.

Learn more biomedcentral.com/submissions 